\title{
IMPACT AREA OF POLITICAL COMMUNICATION: CASE STUDY (SPANISH ELECTIONS 2004)
}

\author{
Fermín Bouza Álvarez \\ Universidad Complutense \\ Raquel Rodríguez Díaz \\ Universidad Rey Juan Carlos \\ raquel.rodriguez@urjc.es
}

\section{Summary}

This work gathers the main results of a study which focused on voter behaviour in the Spanish General Elections in 2004, held on the 14th March, only a few days after the terrorist bombings of trains in Atocha Station on the 11th of March. Using the hypothesis of the impact area of political communication, we have anaylsed the most important issues for public opinion during the 20002004 legislature, paying attention to the months leading up to the elections. The elections were marked by the bombings in which the issues of terrorism, unemployment and housing were the three most serious problems faced by the Spanish population according to both the public and the personal agenda, thus making them keys issues interested in political communication.

Keywords: Public agenda, personal agenda, agenda-setting, elections and Spain.

\section{INTRODUCTION}

This article is the result of a talk given by Fermín Bouza and Raquel Rodríguez at the international congress of the International Communication Association (ICA) held in New York in 2005, in a monographic panel focusing on the relationship between communication and terrorism. The piece of work, the original title of which was "Examining the Spanish Public Agenda, Personal 
Agenda and "Impact Area" between March 11 to March 14, 2004" was never published as an article although it was our intention to do so. It seemed right to me to bring to light, in this journal, one of the most relevant concepts with which Professor Bouza contributed to the academic sphere of political communication: the impact area. This concept centers on the search for a scientific interpretation of the opinions which we, as citizens, express when we differentiate between the public and personal agendas.

In this introduction we have revised some of the theoretical elements of the article which gave its name to the concept of the impact area of political communication (Bouza, 2004). These are essential for the reader's understanding of the case study as a whole, since they were not included in the original text of the ICA. In a Spanish version of Bouza's article (2004), the summary contains the following which was published on the professor's own webpage ${ }^{1}$ :

This article is a reflection on media changes and their repercussion in Politics and in Political Communication; it also hopes to be a historicalnatural interpretation of the determinations of the communications media: human beings have always been subjected to dark forces of extraordinary collective influence, and have always come out ahead in their autonomy. In the end, it is this strength of opinion that paved the way for Democracy and that attempts to keep Democracy free amidst the most undesirable pressures. A more detailed analysis of what is called the impact area of Political Communication is also proposed for the purpose of improving our knowledge about individuals' relationships with public interests. This impact area is the theoretical place in which individuals integrate their personal interests (personal agenda) and their public interests (public agenda).

From a theoretical framework in which different aspects of democratic systems are considered, numerous authors state that the media have fundamental functions, from different perspectives and for different reasons (Swanson, 1994; Shulz, 1999; Blumler \& McQuail, 1969; McCombs, 2004) in the processes of political communication. Other texts highlight the ability of television and internet to be creators of "a new world of global political communication" (DeLuca \& Peeples, 2002). Individuals find out about how politics and politicians behave because the press inform and give an opinion about them, thus framing issues on the media agenda (Entman, 1993; 2004) or using clear and precise reference frameworks which help to simplify and interpret the complicated world of reality.

\footnotetext{
${ }^{1}$ Fermín Bouza Álvarez, personal web, Sociology VI Depart., Facultad de Ciencias de la Información de la Universidad Complutense. http://pendientedemigracion.ucm.es/info/socvi/BOUZA/NUEVA1/Textos/impactesp.pdf
} 
In that sense, individuals learn from the media to allocate a certain importance to any given news story which is similar to the relevance afforded to it by the media. This is revealed by the agenda-setting studies (McCombs and Shaw, 1972; McCombs, 2004), which show that, normally, when an issue has a greater presence in the media agenda, that issue will increase in importance on the public agenda, i.e., as a reflection of public opinion.

The involvement of individuals in the public agenda, which they, themselves, define as a collective, is important but not absolute. Bouza (2004) establishes that individuals hold different groups of personal interests which are separate, to a certain extent, from the public, general or collective interests which feature on the public agenda. This differentiation between the issues or problems which individuals mention as problems for the country and their own personal ones (the personal agenda) leads to a differentiation of interests - the object of analysis of this article - making it possible to find an intersection of issues which are common to the public and personal agendas, called the "impact area" (Figure A).

Figure A: Impact Area

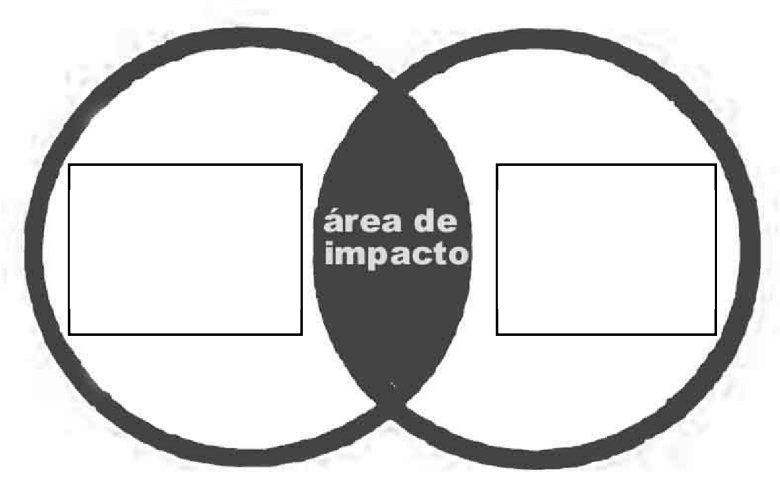

Fuente: Bouza, F. (2004): "The Impact Area of Political Communication: Citizenship Faced with Public Discourse", International Review of Sociology-Revue Internationale de Sociologie, Vol. 14, No. 2.

In that sense and, used instrumentally to detect the degree of interested of individuals in political communication, the definition of impact area is considered as follows (Bouza, 2004: 250):

The impact area would be that subject area that is most sensitive to public communication in general and to political communication in particular, because it is the area in which the individual feels a clear coincidence between the country and himself: a mixed agenda that has the strength of what is general and what is specific. Because of this, this seems to be the agenda that the individual feels most inclined to exercise pressure to achieve, while at the same time the individual is most receptive to any 
communication made about this block of mixed subjects. We can define the impact area operatively as the greater or lesser coincidence in the three most often mentioned subjects on both agendas, starting with the public agenda as the initial reference.

Those issues which feature as the most relevant in the public and personal agendas and, in addition, occupy similar or the same ranking in both agendas would be the object of closer attention for individuals. In that sense, in particular those which appeared in the top three positions in both agendas would become "star issues" in party communication (Ibid. pp.251-252):

Because they are the ones that occupy the public-personal sphere most intensely, with this public-personal sphere understood to be that part of the public sphere that is most perceived from the personal sphere, the place of public communication in which the individual situates herself the most, in the most individual way. We have to assume that the subjects or topics of the public agenda integrate themselves into the apparently altruistic arguments on public subjects, too, similar to what the Anglo-Saxons call public issue arguments (Johnson, 2002), and which define individuals' public rhetoric, while the personal agenda includes the topics that make up the arguments on private or personal subjects, the personal issue arguments. Where both meet, we find the mixed topics and the mixed arguments of individuals that act from this theoretical place that I call the impact area and that, hypothetically, define the highest degree of receptivity in political communications. The relationships between the perceived public agenda (or what the individual takes the public agenda to be at each moment) and the personal agenda should be similar to the relationships between personal opinion and perceived public opinion (Joslyn, 1999), complex relationship which it is not my task to evaluate at this moment.

At any rate, whatever the relationships between personal opinion and public opinion, it is possible to find out what the consequences of these relationships are in the impact area, in order to determine, at a specific moment, their state in relation to the agenda. In this sense, the impact area can show (for all of a survey sample, but also, and above all, for specific collectivities according to class, culture, habitat, etc.) a collectivity's implication in the public agenda at a given moment. In an interesting paper, McCombs (1999) analyzes what he calls personal involvement with issues on the public agenda, taking the Public Agenda to be a projection of various types of personal interests, including altruistic or recreational interests, as well as others. There is no doubt that this is how it is: 
there is always a reason for doing something, but for analytic purposes, it may also be convenient to compare the Public Agenda with the Personal Agenda, because in the first the question itself requires a special effort to altruistically objectify the interests (Civic duty) and in the second there is an intentionally selfish perspective in the question itself. This is another way of analyzing the Public Agenda, and I propose this as a complementary way. The motives are less important than the result of this complex mixture of things that make the Public and Personal Agendas differ at times.

\section{ELECTORAL PROCESS.}

The paper we are presenting is part of a developing interdisciplinary research project financed by the Spanish Ministry of Education and focused on electoral behavior ${ }^{2}$. The results that we are advancing are only a very small part of ongoing research that will be completed with aspects linked to political science, the agenda of the communications media, and the demoscopic analysis of the evolution of Spanish people's vote during recent legislatures ${ }^{3}$. Here we will focus on some of the aspects to take into account in order to understand the context in which the Spanish general elections of March 14, 2004 unfolded. Elections that were affected by the eruption and commotion of the March 11 terrorist attacks in the city of Madrid (Álvarez de Toledo, 2004; Malalana, 2008; Lago \& Montero, 2004; Michavila, 2005; Olmeda, 2005; Rodríguez 2016; Sampedro, 2005; Santamaría (2004); Vara, Rodríguez, Giménez \& Díaz, 2006).

The study begins with the analysis of the issues that the Spanish people considered most important for the country starting in the month of September 2000, coinciding with the first year of the Partido Popular's (PP) second legislature with José María Aznar as president. We will group these issues together as the public agenda and we will see how these issues, considered by public opinion to be the most important problems during the PP government's last legislature, evolved. We will add to the analysis what we call the personal agenda, that is,

\footnotetext{
2 Research project financed by the Ministry of Science and Technology "Voto racional y control en la democracia representativa: Criterios de evaluación de la gestión del gobierno y comportamiento electoral. El caso español 1986-2004". Investigador responsable: Fermín Bouza Álvarez (BSO2000-0747-C02-01).

${ }^{3}$ Some examples of work which is either directly or indirectly linked to or which are heirs of this first research project are: González, J. J. (2002), Las elecciones generales del 2000. Voto ideológico / voto racional, Revista Internacional de Sociología, 32, 7-33; Rodríguez. R. (2005). Miedo post 11-M y terrorismo en España. Recerca: revista de pensament i anàlisi, (5), 127-142. Rodríguez, R. y Bouza, F. (2007). La inseguridad ciudadana en las agendas pública y personal de los españoles (2000-2004) / Citizen Insecurity in the Public and Private Agenda of the Spanish Population (2000-2004). Política y Sociedad, 44(3), 183-196. González, J. J. y Bouza F. (2009). Las razones del voto en la España democrática, 19772008 (Vol. 296). Madrid: Los libros de la Catarata; Rodríguez, R. y Castromil, A. R. (2010). La circulación social de los encuadres periodísticos en tiempo de campaña electoral: Transmisión, influencia y atribución de responsabilidad. ZerRevista de Estudios de Comunicación, 15 (29), 193-212; Castromil, A. y Rodríguez, R. (2011) Terrorismo con y sin tregua. Políticos, ciudadanos y medios de comunicación. Revista TELOS (87), 46-56; Bouza, F., González, J. J., Rodríguez, R., Castromil, A. (2008). “Voto racional y agenda mediática. Propuesta de seguimiento de la legislatura a través de grupos experimentales". En M. J. Canel y M. Gurrionero). Estudios de comunicación política. Libro del año 2008 (pp. 501-520). Madrid: Servicio de publicaciones de la Universidad Complutense.
} 
the issues (problems) that worry citizens most in relation to themselves. From this perspective, we are placing this paper in the framework of the study of citizens' agendas, both public and personal, approaching some of the typical issues of the Agenda Setting Theory focus (McCombs \& Shaw, 1972).

At the beginning of the legislature (2000), the Partido Popular (PP) governed with an absolute majority; as time went on, the distance between the PP and its main rival in the opposition, the Partido Socialista (PSOE), lessened, reaching a difference in direct vote intention of $3.4 \%$ with respect to the PSOE in the month of January-February (pre-electoral study Centro de Investigaciones Sociológicas-CIS ${ }^{4}$ ). Only days before the elections and the terrorist attacks, the polls gave different results for the direct or estimated vote intention: Noxa (a company near to the PSOE but working for the daily newspaper La Vanguardia, which is rather conservative) forecast a PP victory by a margin of $2.2 \%{ }^{5}(41.4 \%$ $39.2 \%$ ) of the estimated vote intention in contrast with other demoscopic companies that gave a broader estimated vote intention (between 5 and 9.5 percentage points). Noxa's direct vote intention was $31.2 \%$ for the PP and $30.9 \%$ for the PSOE. That is, the direct vote intention showed a much lower difference (CIS January/February: 3.4; Noxa -March: 0.3) than the estimated vote intention. We should add that (the data follows) the company TNS-Demoscopia (closer to conservative media, such as the daily newspaper ABC, for which it did electoral polls) gave a difference in direct vote intention in favor of the PSOE (March 10, the eve of the bombings) of $1 \%$ (23.9\% for the PP and $24.9 \%$ for the PSOE). These data indicate the magnitude of the problem of attempting to reconstruct the demoscopic dynamics of these days. But we can talk about communication and communication management.

During the 2000-2004 legislature, different issues gained relevance and became present as problems for the citizens, serving to measure the various policies that the executive branch adopted to resolve them. The increased precariousness of employment, a general strike, immigration, and crime are some of the issues that affected the PP most during the last period. Additionally, there were the issues of Spain's implication in the war of Iraq, with strong citizen opposition, a dizzying increase in the price of housing, and the ecologic disaster of the oil tanker Prestige. The supporting pillars of the PP government were a certain stabilization in the State treasury, the decrease in unemployment, and the fight against terrorism, with the weakening of ETA. In the context of this politicalelectoral situation, we will present the evolution of the important issues as perceived by the public, understood above all as the voting public, presenting it under the subtitles of the public and personal agendas.

\footnotetext{
${ }^{4}$ Study Num. 2.555, January-February 2004

${ }^{5}$ La Vanguardia, March 7, 2004. http://hemeroteca.lavanguardia.com/preview/2004/03/07/pagina-1/33651159/pdf.html
} 


\section{THE ISSUES THAT WORRIED SPANISH CITIZENS MOST, 2000-2004.}

The data given in the two agendas analyzed come from tracking the different issues throughout the legislature in the CIS barometers (September 2000 May 2004). In Agenda-Setting studies, Public Agenda is the response that survey subjects give to the survey question that is formulated as follows in Spain (CIS): To begin with, in your opinion, what are the three main problems that exist at present in Spain? (Spontaneous response). (Multi-response: maximum of three answers). Similarly, we give the name Personal Agenda (or PublicPersonal Agenda) (Bouza, 2004) to the response that survey subjects give to the survey question that is formulated as follows in Spain (CIS): Which three problems personally affect you most? (Spontaneous response). (Multi-response: maximum of three answers).

\section{Graph 1. Evolution of Main Issues on the Public Agenda}

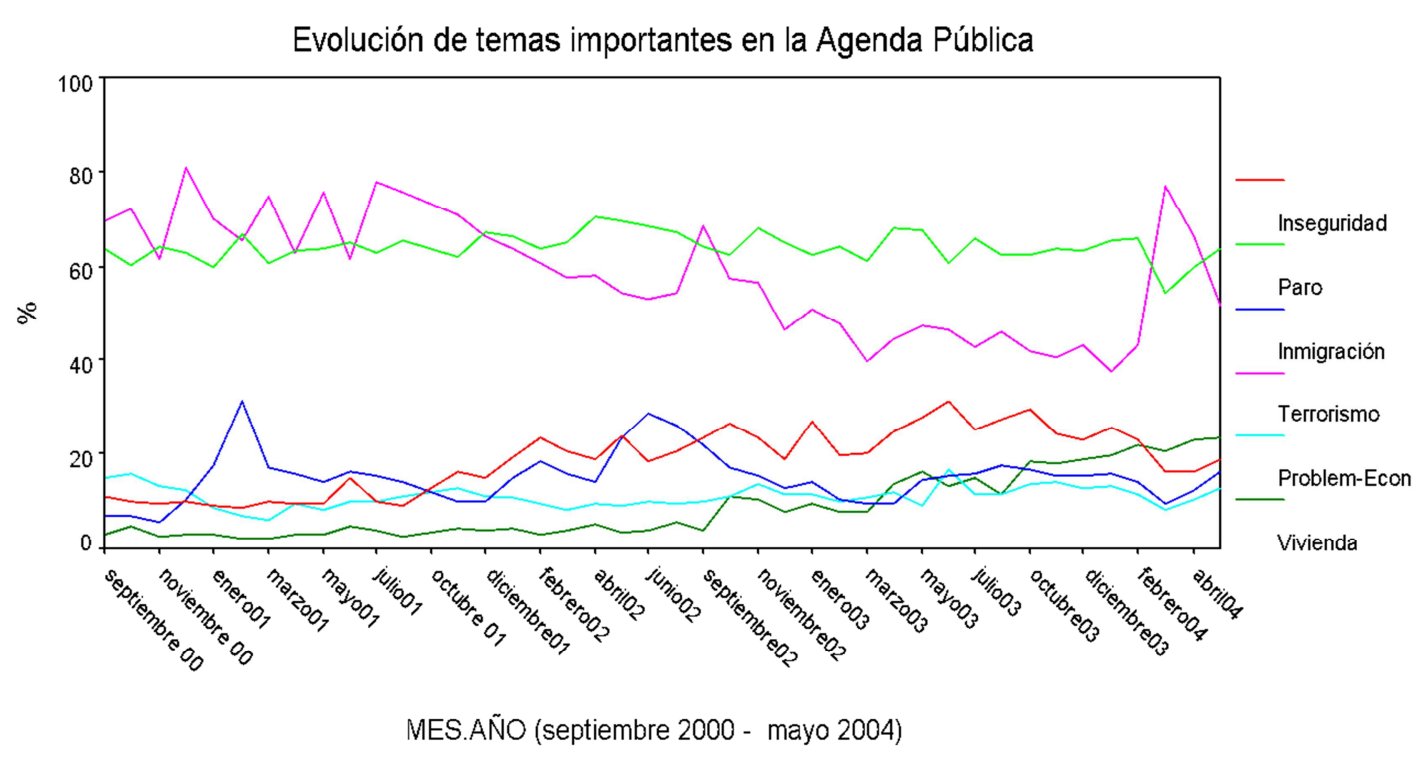

As shown in Graph 1, unemployment and terrorism have been the star issues on the public agenda, always having the most outstanding percentages and never losing their position in first or second place. When unemployment has held first place (much oftener than terrorism), terrorism has been in second place, and viceversa, according to the events of the moment. Therefore, unemployment has been, by far, the issue that has most worried Spanish citizens.

Unemployment's and terrorism's domination of the public agenda has only left third place for other issues to dispute. In this third place, we find a much higher fluctuation of issues and relevance, with reference to the percentage of these issues. As Graph 1 shows, the problems with greater presence and continuity on the agenda, with the exception of unemployment and terrorism, have been crime, immigration, housing, and economic problems. In September 2000, both 
crime and immigration are somewhat present on the agenda, with percentages of $11 \%$ and $6.7 \%$ respectively; in February 2004, they had doubled and crime was at $22.9 \%$ (third place) and immigration at $13.9 \%$. Similarly, housing gains presence and positions on the agenda as the legislature unfolds. In September 2000, housing begins at 3\%, taking the coveted third place in March 2004 with $21.8 \%$, after the attacks. Likewise, the economic problems (stated thus, as "economic problems" because they also exist in other forms such as unemployment, etc.) appear as a more constant issue on the agenda, in addition to having a strong percentage presence throughout these four years.

\section{Graph 2. Evolution of the Public Agenda (Unemployment, Terrorism and Housing)}

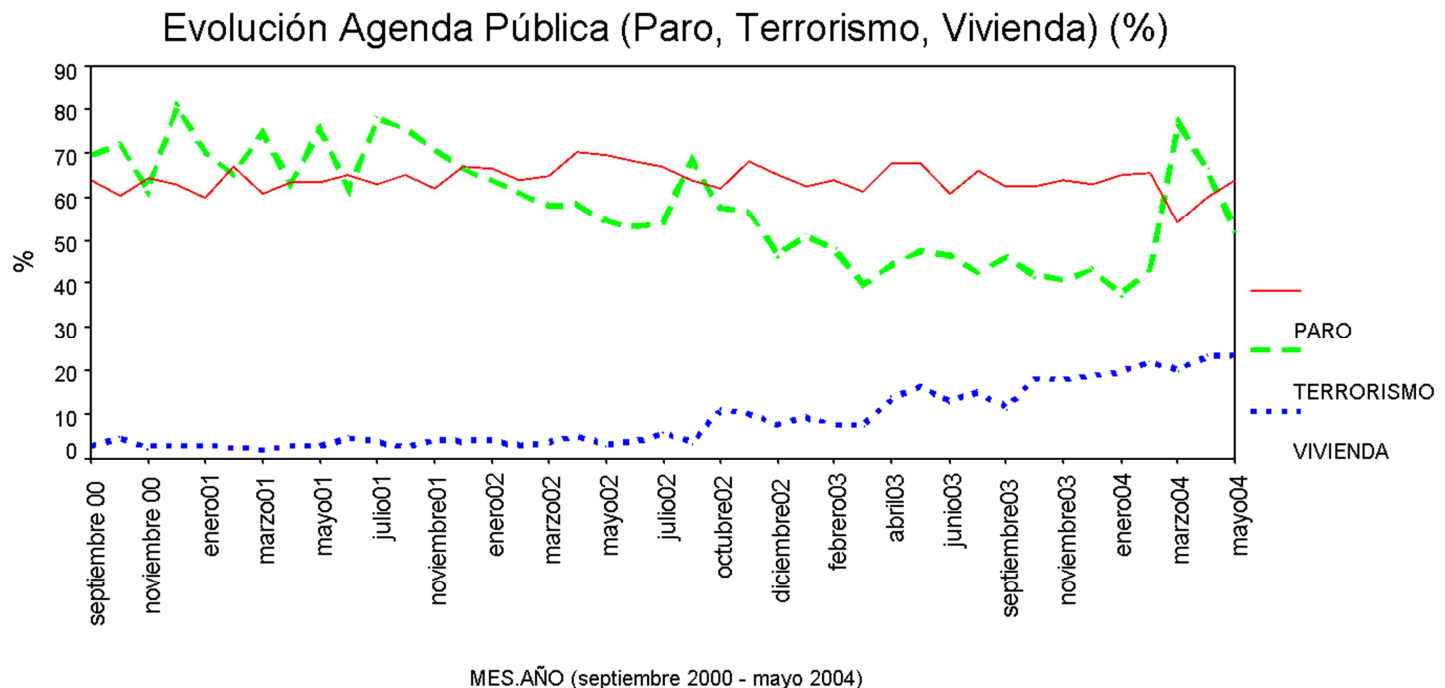

While this was happening on the public agenda, other things were happening on the personal agenda and other issues were the most worrying, although we will focus only on unemployment, terrorism, housing, and economic problems (see Graph 5), as these were the issues that stood out most on both the public and private agendas in the months before the elections. As Graph 3 shows, the percentages achieved on the personal agenda are lower because they are linked to a different distribution than on the public agenda; this does not, however, affect the rankings, positions, or places shown in this paper. 


\section{Graph 3. Evolution of the Personal Agenda (Unemployment, Terrorism and Housing)}

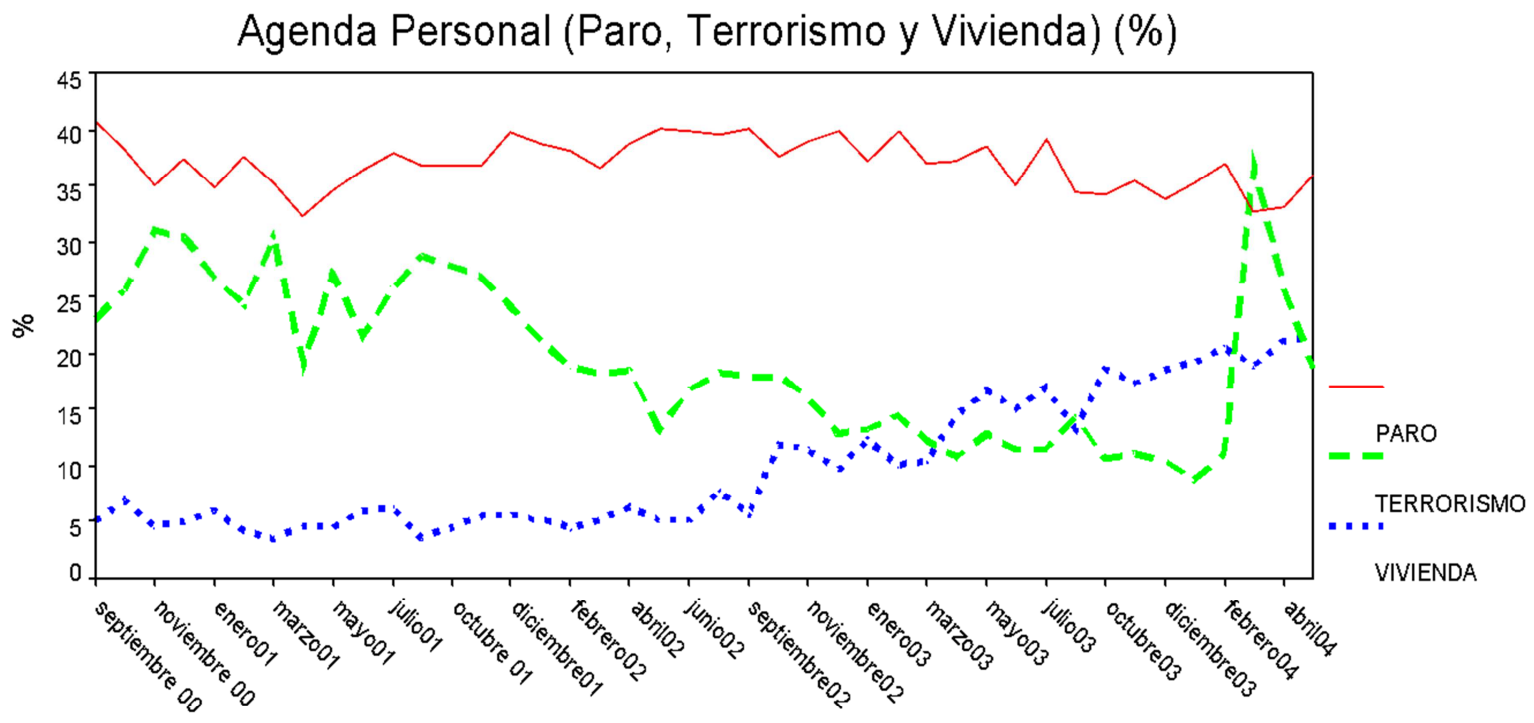

MES.AÑO Septiembre 2000 - Mayo 2004

On the personal agenda, we can see how unemployment has always been issue number one and has never been supplanted during the period under analysis, with the exception of the month of March 2004, when terrorism took its place. However, this last issue (terrorism) went from second place in September $2000(23 \%)$ to sixth place in January $2004(8.8 \%)^{6}$. On the contrary, while this issue decreased in relevance, crime increased and housing went up in the ranking starting in September 2000 (5.1\%), steadily gaining positions and speedily rising as a personal issue or problem for Spanish people; housing took third place in the ranking (17\%) in the month of July 2003, and second place $(20,5 \%)$ in February 2004 . The presence of economic problems on the personal agenda is important and they appear frequently among the first four rankings.

As we pointed out before, Graph 2 and Graph 3 show the evolution of the three most relevant issues on both agendas. On the personal, agenda, we can see that unemployment is the issue that maintains first place, in a very stable manner, followed by terrorism, although housing can be observed in third position from April 2003 onward. Housing only falls to fourth place or rank (13.3\%) in September 2003, finally climbing to second place in February 2004. From the public agenda perspective, there are fewer variations among the three issues, with a timid rise in housing and the descent of terrorism as a public worry from July 2001 onwards being observed.

\footnotetext{
${ }^{6}$ Rodríguez y Bouza (2007). La inseguridad ciudadana en las agendas pública y personal de los españoles (2000-2004) / Citizen Insecurity in the Public and Private Agenda of the Spanish Population (2000-2004). Política y Sociedad, 44(3), 183-196.
} 


\section{PUBLIC AND PERSONAL AGENDAS IN THE IMPACT AREA OF PO- LITICAL COMMUNICATION IN THE MARCH 14 ELECTIONS. CON- CLUSIONS FOR A DEBATE.}

The public and personal agendas on the March 2004 CIS barometer ${ }^{7}$ carried out from March 16 to March 21, two days after the March 14 general elections, show the following hierarchy in their first three issues:

TABLE $\mathbf{n}^{\mathbf{0}} \mathbf{1}$

\begin{tabular}{|c|c|c|c|}
\hline MARCH 2004 & FIRST ISSUE & SECOND ISSUE & THIRD ISSUE \\
\hline PUBLIC AGENDA & Terrorism, ETA & Unemployment & Housing \\
& $(76.9 \%)$ & $(54.2 \%)$ & $(20.3 \%)$ \\
\hline PERSONAL AGENDA & Terrorism, ETA & Unemployment & Housing \\
& $(36.7 \%)$ & $(32.7 \%)$ & $(18.9 \%)$ \\
\hline
\end{tabular}

The differences in percentages have to do with the different distribution that the issues have on both agendas, but they do not affect the rankings, which coincide. If we assume the Impact Area hypothesis ${ }^{8}$, (the greater the coincidence between issue and ranking on both agendas, the greater the incidence or impact of political communication on these issues: full identification between personal and public agendas), we could say that Terrorism takes on a central function in the efficacy of Political Communication, and that this central function orients the vote in this (political) direction, which frames the economic issues (Unemployment, Housing), shifting them and causing them to be interpreted from the thematic priority of Terrorism. In other words, the March 11 terrorist action, by moving the relevance of Terrorism up to the first rank on both agendas and increasing its percentages, had a substantial influence on the framing of the political-economic situation as a whole and shifted the vote from the economic vote to the political vote.

The barometer previous to the March barometer (February Barometer, CIS ${ }^{9}$ ) shows this issue distribution (carried out February 20-27):

\footnotetext{
7 Study 2558, March 2004, CIS (Centro de Investigaciones Sociológicas): http://www.cis.es/cis/export/sites/default/Archivos/Marginales/2540_2559/2558/ES2558.pdf

8 Bouza, F. (2004). The Impact Area of Political Communication: Citizenship Faced with Public Discourse, International Review of Sociology - Revue Internationale de Sociologie, Vol. 14, No. 2.

9 Study 2556, February 2004, Centro de Investigaciones Sociológicas (CIS): http://www.cis.es/cis/export/sites/default/Archivos/Marginales/2540_2559/2558/ES2558.pdf
} 
TABLE no 2.

\begin{tabular}{|c|c|c|c|}
\hline FEBRUARY 2004 & FIRST ISSUE & SECOND ISSUE & THIRD ISSUE \\
\hline PUBLIC AGENDA & Unemployment & Terrorism, ETA & Crime \\
& $(65.6 \%)$ & $(43.2 \%)$ & $(22.9 \%)$ \\
\hline PERSONAL AGENDA & Unemployment & Housing & Crime \\
& $(37 \%)$ & $(20.5 \%)$ & $(15.6 \%)$ \\
\hline
\end{tabular}

The differences are obvious. The demoscopic situation, if we take the most optimistic vote estimate for the Partido Popular (Empresa TNS-Demoscopia, which worked, among others, for the company of the conservative daily newspaper $A B C$ ), showed a situation for the direct vote that evolved as follows in the subsequent days ${ }^{10}$ :

TABLA no 3 .

\begin{tabular}{|l|c|c|c|c|c|c|}
\hline $\begin{array}{c}\text { DAYS/DIRE } \\
\text { CT VOTE } \\
(\%) \text { PP/PSOE }\end{array}$ & $\begin{array}{c}\text { MARCH } \\
\text { 8th }\end{array}$ & $\begin{array}{c}\text { MARCH } \\
\text { 9th }\end{array}$ & $\begin{array}{c}\text { MARCH } \\
\text { 10th }\end{array}$ & $\begin{array}{c}\text { MARCH } \\
\text { 11th }\end{array}$ & $\begin{array}{c}\text { MARCH } \\
\text { 12th }\end{array}$ & $\begin{array}{c}\text { MARCH } \\
\text { 13th }\end{array}$ \\
\hline PP & 21.1 & 26.8 & 23.9 & 24.1 & 23.6 & 20.7 \\
\hline PSOE & 20.6 & 19.1 & 24.9 & 15.1 & 18.9 & 19.7 \\
\hline
\end{tabular}

The direct vote has, in recent years and elections, been the best tendency predictor. And it is again here. But these data also show the immediate effects of the attacks: there is not so much an increase for the PP as a decrease in the direct vote for the PSOE of 9.8 percentage points. Terrorism as an issue for interpreting the situation (as a framing issue, but also as a priming issue for any immediate interpretation, with very high relevance), will mark voting behavior in two ways. In the first place, and following the classic hypothesis, the response to any attack against the State is an increase in support for the State (represented by the Government, although in this case the support was given negatively, by denying votes to the PSOE). In second place, in the face of the government management of the terrorist act (this is probably the best way to express what really occurred during these days without having to resort to the complex and thorny issue of the lie, which was the popular majority percep-

\footnotetext{
10 TELECINCO.com news. The tracking data were on the Telecinco web page; TNS-Demoscopia was in their employment during these electoral dates. Our efforts to get the matrices of these surveys were unfruitful, in spite of permission from Telecinco.
} 
tion $^{11}$ ) support is shifted to the main opposition party. At any rate, the framing of Terrorism should be at the center of the interpretation of electoral behavior.

The evolution of the main issues in both agendas (Graphic 4 and Graphic 5) can show us how it was the evolution of impact area of political communication between January to April 2004.

\section{GRAPH 4. Evolution of Main Issues on the Public Agenda (Ranking) Evolución Temas Importantes en Agenda Pública (rango)}

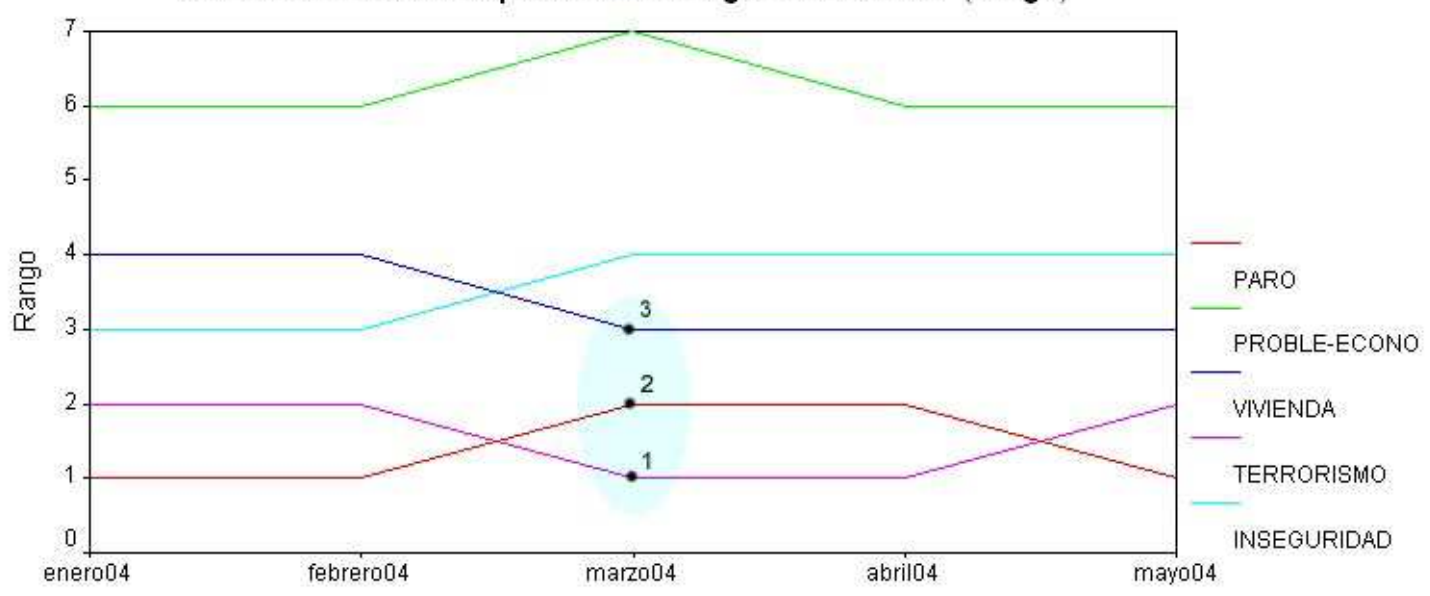

MES.AÑO (Enero 2004 - Mayo 2004)

\section{GRAPH 5. Evolution of Main Issues on the Personal Agenda (Ranking)}

Evolución temas principales en la Ag.Personal. (Rango)

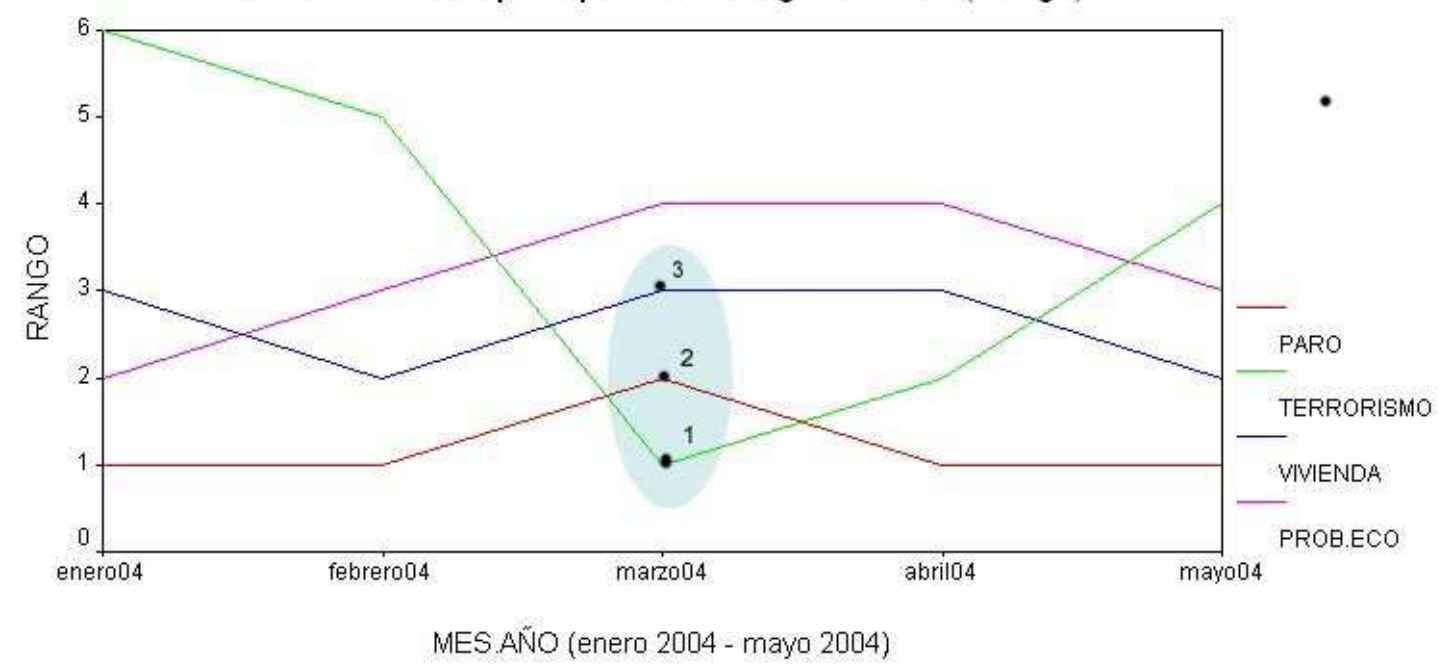

${ }^{11}$ In the last few days, do you think that information has been manipulated/hidden?:

YES: 64,7\%; NO: 24,7\%; DOES NOT KNOW: 10,5\%; DOES NOT ANSWER: 0,1\%. "Puslsómetro" Survey March 22, 2004, Cadena SER: http://cadenaser.com/ser/2004/03/22/espana/1079916611_850215.html 
Terrorism, unemployment and housing were the three "star issues" of political communication during the elections of 2004, symbolizing the meeting of "public" and "personal" with the mixed argument of individuals who act from a perfect impact area (both issues, themselves, and their respective position in the two agendas coincide). To put it another way, we could say that these three issues made up the backbone of political communication during the Spanish elections, thus giving greater visibility in the public debate to those parties which positioned them better in their message.

\section{REFERENCES.}

Álvarez De Toledo, C. (2004). Cuatro días de marzo: la verdad sobre el 11-M. Madrid: Planeta.

Johnson, A. J. (2002). Beliefs about arguing: A comparison of public issue and personal issue arguments, Communication Reports, pp. 99-111.

Joslyn, M.R. (1999). Perceiving public opinion of political figures: Examining the link between individual and collective opinion, International Journal of Public Opinion Research, fall 1999, pp. 213-232.

Blumler, J. G., \& McQuail, D. (1969). Television in politics: Its uses and influence. University of Chicago Press.

Bouza, F. (2004). The impact Area of Political Communication: Citizenship Faced with Public Discourse, International Review of Sociology - Revue Internationale de Sociologie, Vol. 14, nํㅡ 2, pp. 245- 259.

Bouza, F., González, J. J., Rodríguez, R., \& Castromil, A. (2008). “Voto racional y agenda mediática. Propuesta de seguimiento de la legislatura a través de grupos experimentales". En M. J. Canel y M. Gurrionero). Estudios de comunicación política. Libro del año 2008 (pp. 501-520). Madrid: Servicio de publicaciones de la Universidad Complutense.

Castromil, A., \& Rodríguez, R. (2011). Terrorismo con y sin tregua. Políticos, ciudadanos y medios de comunicación. Revista TELOS (87), pp. 46-56.

DeLuca, K., \& Peeples, J. (2002). From public sphere to public screen: Democracy, activism, and the" violence" of Seattle. Critical studies in media communication, 19(2), pp. 125-151.

Entman, R. M. (1993). Framing: Toward clarification of a fractured paradigm. Journal of communication, 43(4), pp. 51-58.

Entman, R. M. (2004). Projections of power: Framing news, public opinion, and US foreign policy. Chicago: University of Chicago Press.

González, J. J. (2002). Las elecciones generales del 2000. Voto ideológico / voto racional, Revista Internacional de Sociología, 32, pp. 7-33. 
González, J. J., \& Bouza F. (2009). Las razones del voto en la España democrática, 1977-2008 (Vol. 296). Madrid: Los libros de la Catarata.

Lago, I, \& Montero, J. R. (2004). “Los mecanismos del cambio electoral. Del 11M al 14M", Claves de la razón práctica, 149, pp. 36-44.

Malalana, A. (2008). Aproximación historiográfica al 11-M (Vol. 4). Madrid: CEU

Ediciones.http://www.uspceu.com/instituto_democracia/pdf/publicaciones/doc umentos-trabajo/malalana.pdf (visita realizado el 5 de junio de 2017).

McCombs, M, \& Shaw, D. L. (1972). The Agenda-setting function of the mass media, Public Opinion Quarterly, n 36, pp. 176-187.

McCombs, M. (1999). Personal Involvement with issues on the public agenda, International Journal of Public Opinion Research, no11, pp. 152 -168.

McCombs, M. (2004). Setting de Agenda. Cambridge, Polity Press.

Michavila, N. (2005). "Guerra, terrorismo y elecciones: incidencia electoral de los atentados islamistas de Madrid", Documento de trabajo no 13, 13 de marzo de 2005, Real Instituto Elcano, Madrid.

Rodríguez. R. (2005). Miedo post 11-M y terrorismo en España. Recerca: revista de pensament $i$ anàlisi, (5), pp. 127-142.

Rodríguez, R. (2016). “Bases de datos para el análisis del contenido de la prensa: Atentado terrorista 2004 en Madrid" en M. Sánchez y C. Oliva, Formas de comunicación en el siglo XXI (pp. 209-227). Madrid: Dykinson.

Rodríguez, R., \& Bouza, F. (2007). La inseguridad ciudadana en las agendas pública y personal de los españoles (2000-2004) / Citizen Insecurity in the Public and Private Agenda of the Spanish Population (2000-2004). Politica y Sociedad, 44(3), pp. 183-196.

Rodríguez, R., \& Castromil, A. R. (2010). La circulación social de los encuadres periodísticos en tiempo de campaña electoral: Transmisión, influencia y atribución de responsabilidad. Zer-Revista de Estudios de Comunicación, 15 (29), pp. 193-212.

Sampedro Blanco, V. (2005). 13-M, Multitudes online. Madrid: Catarata.

Santamaría, J. (2004). “El azar y el contexto. Las elecciones generales de 2004”, Claves de la razón práctica, 146, octubre, pp. 28-43.

Swanson, D. L. (1995). El campo de la Comunicación Política. La democracia centrada en los Medios (pp. 3-24), en Muñoz-Alonso, A., \& Rospir, J. L. (eds), Comunicación Política. Madrid: Editorial Universitas. 
Schulz, W. (1999). Television and declining political trust: How Germans react to changes in the media system. In International Communication Association Conference. San Francisco, CA.

Vara, A., Rodríguez, J., Giménez, E., \& Díaz, M., (Eds), (2006). Cobertura informativa del 11M. Pamplona: EUNSA.

\section{WEB}

Bouza, F. Página personal del Catedrático de Opinión Pública Fermín Bouza Álvarez, Departamento de Sociología VI, Facultad de Ciencias de la Información de la Universidad Complutense. http://pendientedemigracion.ucm.es/info/socvi/BOUZA/NUEVA1/Textos /impactesp.pdf (visita realizada el 7 de julio de 20017).

Centro de Investigaciones Sociológicas (CIS). Estudio №2.556, febrero 2004, Centro de Investigaciones Sociológicas (CIS). http://www.cis.es/cis/export/sites/default/archivos/Marginales/2540_2559 /2558/ES2558.pdf (visita realizada el 18 de mayo de 2017).

Centro de Investigaciones Sociológicas (CIS). Estudio № 2.558, marzo 2004, Centro de Investigaciones Sociológicas (CIS). http://www.cis.es/cis/export/sites/default/Archivos/Marginales/2540_255 9/2558/ES2558.pdf (visita realizada el 18 de mayo de 2017).

La Vanguardia, 7 de marzo de 2004. http://hemeroteca.lavanguardia.com/preview/2004/03/07/pagina1/33651159/pdf.html (visita realizada el 7 de mayo de 20017).

Pulsómetro, encuesta, 22/3/2004. Cadena SER. http://cadenaser.com/ser/2004/03/22/espana/1079916611_850215.html (visita realizada el 18 de mayo de 2017).

FERMín BOUZA ÁLVAREZ. Catedrático de Opinión Pública en la Universidad Complutense de Madrid. Investigador y escritor, especializado en el estudio de los medios de comunicación, la realidad política y el comportamiento electoral.

RAQUEL RODRÍGUEZ DÍAZ. Profesora e investigadora en la Universidad Rey Juan Carlos, con una extensa experiencia en investigación de Agenda Setting y su aplicación empírica en diferentes ámbitos. 